\title{
Determination of Curve Number for snowmelt-runoff floods in a small catchment
}

\author{
L. Hejduk ${ }^{1}$, A. Hejduk ${ }^{2}$, and K. Banasik ${ }^{1}$ \\ ${ }^{1}$ Warsaw University of Life Sciences - SGGW, Hydraulic Engineering, Warsaw, Poland \\ ${ }^{2}$ Warsaw University of Life Sciences - SGGW, Laboratory Water Center, Warsaw, Poland \\ Correspondence to: L. Hejduk (leszek_hejduk@sggw.pl)
}

Received: 12 March 2015 - Accepted: 12 March 2015 - Published: 11 June 2015

\begin{abstract}
One of the widely used methods for predicting flood runoff depth from ungauged catchments is the curve number (CN) method, developed by Soil Conservation Service (SCS) of US Department of Agriculture. The $\mathrm{CN}$ parameter can be computed directly from recorded rainfall depths and direct runoff volumes in case of existing data. In presented investigations, the $\mathrm{CN}$ parameter has been computed for snowmelt-runoff events based on snowmelt and rainfall measurements. All required data has been gathered for a small agricultural catchment $\left(\mathrm{A}=23.4 \mathrm{~km}^{2}\right)$ of Zagożdżonka river, located in Central Poland. The $\mathrm{CN}$ number received from 28 snowmelt-runoff events has been compared with $\mathrm{CN}$ computed from rainfall-runoff events for the same catchment. The $\mathrm{CN}$ parameter, estimated empirically varies from 64.0 to 94.8 . The relation between $\mathrm{CN}$ and snowmelt depth was investigated in a similar procedure to relation between $\mathrm{CN}$ and rainfall depth.
\end{abstract}

\section{Introduction}

Determination of effective rainfall defined in hydrology as a portion of total rainfall that contributes to runoff is a crucial step in application of rainfall-runoff models. One of the often used approaches is the so called Curve Number (CN) method. This method was created in c. 1950 by USDA Soil Conservation Service (Hawkins et al., 2010). Since this time, the method has been applied for an estimate of effective rainfall in various catchments. In Poland, the method were applied in agricultural catchments (Banasik and Ignar, 1983; Miler, 2012) and urban catchment (Banasik and Pham, 2010) as well. The application of $\mathrm{CN}$ method for snowmelt conditions is rare. However, it is used in continuous modelling (Van Mullen et al., 2002). This paper presents an attempt for application of the $\mathrm{CN}$ method for snowmelt runoff events based on measured snow water content, rainfall and runoff in a small lowland catchment.

\section{Study area and catchment}

\subsection{Location and size of the catchment}

Hydrological field investigation in a river of Zagożdżonka was started by the present Department of Hydraulic Engineering of Warsaw University of Life Science in 1962 at Płachty Stare gauge. Some 20 years later, monitoring of the river flow at Czarna gauge has begun. Since 1991 the investigation has been intensified and the river gauging station at Czarna has been equipped with automatic recorders of rainfall water level and with devices measuring water quality parameters, i.e. temperature, turbidity and sediment transport. Later, an electronic system of data recording, logging and transmitting was installed. Zagożdżonka catchment, shown in Fig. 1 is located in central Poland, about $100 \mathrm{~km}$ south of Warsaw. The catchment area at Czarna is $23.4 \mathrm{~km}^{2}$.

\subsection{Rainfall, snowmelt and runoff}

The mean annual precipitation and runoff are estimated at 610 and $106 \mathrm{~mm}$ respectively, on the bases of 50-year (19632012) data records collected by the Department of Hydraulic Engineering of Warsaw University of Life Sciences 


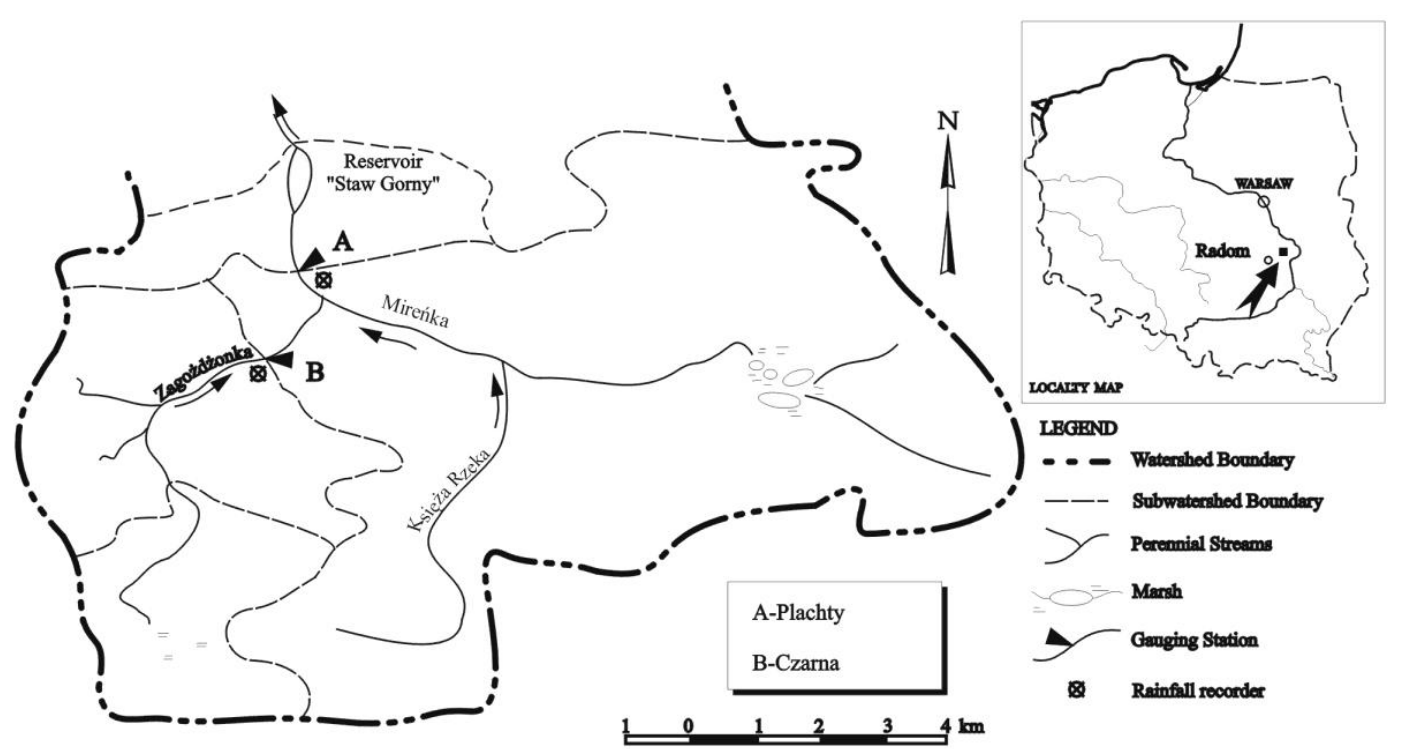

Figure 1. Locality map of the catchment.

at Płachty Stare, except for precipitation data for the period 1963-82. This period of data was taken from available publications of Polish hydro-meteorological service IMiGW for the nearest rain gauge Zwoleń. The maximum precipitation of $941 \mathrm{~mm}$ was recorded in 1974 and the minimum of 414 in 1991. Maximum annual runoff of $209 \mathrm{~mm}$ was measured in 1980 and the minimum of $52 \mathrm{~mm}$ in 1992 . The winter period precipitation (December-February), mainly in the form of snow, is c. $103 \mathrm{~mm}$, i.e $16.9 \%$ of the annual amount (Banasik et al., 2014b). According to the thermal and snowiness classification (Hejduk and Hejduk, 2014), temperate cold and extraordinarily low snowy winters has dominated in Zagożdżonka catchment in time of 2003-2013. The decreasing number of days with thick snow was recently observed. The snow cover in Czarna usually appears at the end of November and disappears at the end of March, resulting in a total number of days with snow, equal to 67 and snowmelt periods 1-4 days long (Hejduk and Hejduk, 2014).

\subsection{Topography, land use and soils}

Topography of Zagożdżonka catchment is typical for lowlands in Central Poland. Absolute relief is $26.5 \mathrm{~m}$ in the (shown as B) in the Fig. 1. The mean slopes of main streams are from 2.5 to $3.5 \mathrm{~m}$ per $1000 \mathrm{~m}$. Local depressions, which do not contribute to direct runoff and sediment yield from the catchment, constitute a significant part of the area $3.8 \mathrm{~km}^{2}$ upstream of Czarna. Land use is dominated by arable land (small grains and potatoes), which occupies about $70 \%$, one fifth $(20 \%)$ being covered by forest and about $10 \%$ for pasture (Banasik, 1994). Sandy soils are the dominant type in the watershed area (light loamy sand $-40.2 \%$; loamy sand $50.5 \%$ and organic soils $-9.3 \%$ ).

\section{$3 \mathrm{CN}$ determination}

\subsection{CN for rainfall-runoff events}

The curve number is a parameter which can be estimated based on existing rainfall-runoff events as well as based on hydrological properties of soils cover conditions and land use. Using rainfall-runoff data, the empirical $\mathrm{CN}$ can be calculated by following the relationship of (Banasik et al., 2014a):

$\mathrm{CN}=\frac{25400}{S+254}$

where $\mathrm{CN}$ is a dimensionless parameter varying from $(0.100>, S-$ maximum potential retention of the particular catchment (mm), 25400 and 254 are numbers arising from recalculation of original equation to metric system. The relation of direct runoff depth $H(\mathrm{~mm})$ and rainfall depth $P$ $(\mathrm{mm})$ is given in a set of equations:

$$
\begin{array}{r}
H=\frac{P-0.2 S^{2}}{P+0.8 S} \text { if } P>2 S \\
H=0 \text { if } P \leq 2 S
\end{array}
$$

After transformation of Eq. (2) against $S$ it is possible to calculate it based on $P$ and $H$ and afterwards of coefficient $\mathrm{CN}$, by use of Eq. (1).

\subsection{CN for snowmelt-runoff events}

The Eq. (2) has been applied for snowmelt events. The main idea was to recalculate measured snow depth into an amount of water based on daily snow sampling (Hejduk and Banasik, 2011). The depth of snow, as well as weight and volume of 
Table 1. Characteristics of 28 snowmelt or snowmelt rainfall events.

\begin{tabular}{llrr}
\hline Category & \multirow{2}{*}{ Unit } & \multicolumn{2}{c}{ Value for events } \\
\cline { 3 - 4 } & & average & range \\
\hline Snowmelt and Rainfall $(M+P)$ & $\mathrm{mm}$ & 28.98 & $5.90-69.30$ \\
Runoff depth $(H)$ & $\mathrm{mm}$ & 3.27 & $0.19-16.17$ \\
Peak discharge $(Q)$ & $\mathrm{m}^{3} \mathrm{~s}^{-1}$ & 0.77 & $0.14-3.44$ \\
$\mathrm{CN}$ & - & 79.3 & $64.0-94.8$ \\
\hline
\end{tabular}

the snow sample were measured using Chomicz snow sampler (Janiszewski, 1988), with daily time step. According to the sampler's construction (cross-section of the pipe), the weight of the snow sample in grams is numerically equal to snow water content in millimetres.

It was assumed that snowmelt runoff from catchment was caused by snowmelt $M(\mathrm{~mm})$ or the sum of snowmelt $M$ and rainfall $P(M P)$ in the case of mixed, snowmelt-rainfall events. This assumption leads to modification of Eq. (2) in the following way:

$H=\frac{(M+P)-0.2 S^{2}}{(M+P)+0.8 S}$ if $P>2 S$

where $M$ is a snowmelt depth (mm) and $P$ is a rainfall depth (mm).

This simple modification was applied to calculate the $\mathrm{CN}$ factor for snowmelt-runoff and snowmelt/rainfall-runoff events.

\section{CN number for snowmelt-runoff snowmelt/rainfall-runoff events with comparison to rainfall-runoff events.}

Using Eqs. (1) and (4) together with daily snowmelt-runoff and snowmelt/rainfall-runoff events, the $\mathrm{CN}$ was estimated for 28 events measured between 1998-2012 for the Czarna gauging station. Basic characteristic of considered events are presented in Table 1.

The CNs estimated from recorded data in comparison to snowmelt $M P$ are presented in Fig. 2. The dots representing $\mathrm{CN}$ and $M P$ pairs of data indicate the relation between those values.

In case of rainfall-runoff data, (Hawkins, 1993; Hawkins et al., 2010) proposed to use an "asymptotic" approach for approximation of $\mathrm{CNs}$ and rainfall $P$ relation after adoption of frequency matching technique. This method assumes, that rainfall depth and direct runoff depth are stored separately and then realigned on the rank-order basis to form $P: H$ pairs of equal return periods (Banasik et al., 2014a). A standard asymptote occurs according to formula 5 when there is a decline tendency of $\mathrm{CN}$ with increase of $P$.

$\mathrm{CN}(P)=\mathrm{CN}+\left(100-\mathrm{CN}_{\infty}\right) \exp \left(\frac{-P}{b}\right)$

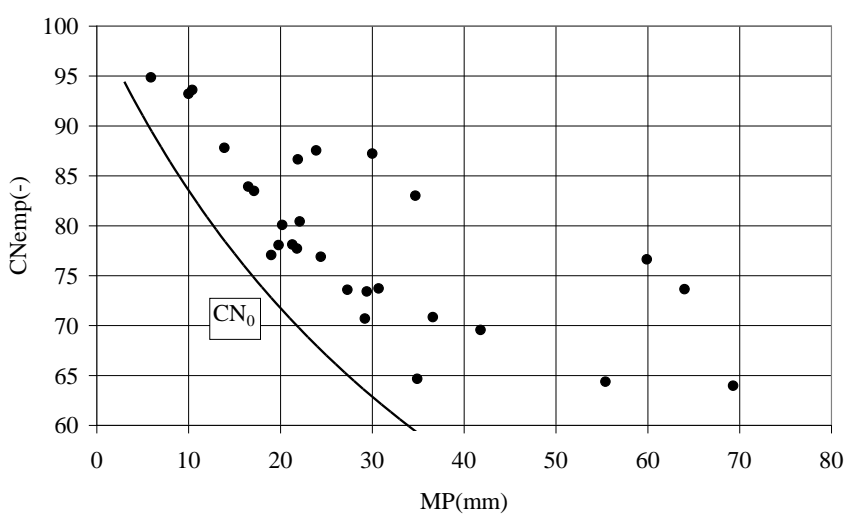

Figure 2. $\mathrm{CN}$ vs. $M P . \mathrm{CN}_{0}$ represent a threshold, below which no runoff occurs until the snowmelt $M P$ in mm exceeds an initial abstraction of $20 \%$ of the maximum potential retention.

where $\mathrm{CN}_{\infty}$ is a constant approached as $P \rightarrow \infty$; and $b$ is a fitted constant.

The analyses conducted for Czarna station after applying matching technique for 71 rainfall and runoff data pairs resulted in Eq. (6) (Banasik et al., 2014b) that is a projection of asymptote proposed by Hawkins (1993). This form of relation was also investigated by other authors (Stewart et al., 2012; Tedela et al., 2011).

$\mathrm{CN}(P)=70.6+29.4 \exp (-P / 22.0)$

where $\mathrm{CN}$ and $P$ are the Curve Number and rainfall depth, 70.6 is a constant approached when $P \rightarrow \infty$ often indicated as $\mathrm{CN}_{\infty}, 29.4$ is a parameter equal $100-\mathrm{CN}_{\infty}$ and 22.0 is a fitted parameter $b$.

The similar procedure was applied for investigating snowmelt-runoff events. It results in determination of new asymptote parameters for snowmelt conditions:

$\mathrm{CN}(M P)=71.3+28.7 \exp (-M P / 18.1)$

with the $r^{2}=0.91$ and standard error $\mathrm{SE}=1.56$

where $\mathrm{CN}$ and $M P$ are the Curve Number and snowfall + rainfall depth, 71.3 is a constant approached when $M P \rightarrow \infty$, and 28.7 is a parameter equal $100-\mathrm{CN}_{\infty}$ and 18.1 is a fitted parameter $b$.

\section{Conclusions}

The CN calculated from measured snowmelt-runoff events show a large variation from 64 to 94.8 with the average value calculated as 79.3. The comparison of $\mathrm{CN}$ and $M P$ suggests decreasing the relation in a similar way to decreasing the $\mathrm{CN}$ and rainfall relation already investigated in this catchment. The parameters of the relation proposed by Hawkins (1993) received for snowmelt-runoff events were closed to parameters received for rainfall-runoff events for the Czarna gauge. The $\mathrm{CN}_{\infty}$ in case of snowmelt-runoff were higher (71.3) in 
comparison to the rainfall-runoff (70.6) and the fitted parameter was lower in case of the snowmelt-runoff events. The $\mathrm{CN}_{\infty}$ obtained for snowmelt can be assumed as an identifying $\mathrm{CN}$ for winter/spring periods for Czarna station in Zagożdżonka catchment. It can be applicable for a design snowmelt/snowmelt rainfall events.

Acknowledgements. This investigation was carried out with financial support from the PL-National Center of Science (NCN) within the research project N N305144540. The support provided by the organization is gratefully acknowledged. The investigation described in this paper has been also conducted as a part of the international research project KORANET (Join Call on Green Technologies) - EURRO-KPS founded by National Center for Research and Development (NCBiR), and by the National Research Foundation (NRF) of Korea.

\section{References}

Banasik, K.: Sedimentgraph model of rainfall event in a small agricultural watershed, Treaties and Monographs, Warsaw Agricultural University Press, Warsaw, Poland, 119 pp., 1994 (in Polish).

Banasik, K. and Ignar, S.: Estimation of effective rainfall using the SCS method on the base of measured rainfall and runoff, Przeglad Geofizyczny (Review of Geophysics), XXVII, 401408, 1983 (in Polish).

Banasik, K. and Pham, N.: Modelling of the effects of land use changes on flood hydrograph in a small catchment of the Płaskowicka, southern part of Warsaw, Annals of Warsaw University of Life Sciences - SGGW Land Reclamation No. 42, 229-240, 2010.

Banasik, K., Krajewski, A., Sikorska, A., and Hejduk, L.: Curve number estimation for a small urban catchment from recorded rainfall-runoff events, Arch. Environ. Prot., 40, 75-86, 2014a.
Banasik, K., Woodward, D. E., and Hawkins, R.: Curve Numbers for Two Agro-Forested Watersheds, World Environmental and Water Resources Congress 2014: Water without Borders, ASCE 2014, 2235-2246, 2014b.

Hejduk, A. and Banasik, K.: Recorded lag times of snowmelt events in a small catchment, Ann. Warsaw Univ. of Life Sci. - SGGW, Land Reclam. 43, 37-46, 2011.

Hejduk, A. and Hejduk, L.: Thermal and snow conditions of winters and winter floods on example of Zagożdżonka River, Ann. Warsaw Univ. Life Sci. - SGGW, Land Reclam. 46, 3-15, 2014.

Hawkins, R. H.: Asymptotic determination of curve numbers from data, Journal of Irrigation and Drainage Division, American Society of Civil Engineers, 119, 334-345, 1993.

Hawkins, R. H., Woodward, D. E., and Van Mullem, J. A.: Continuing evolution of rainfall-runoff and the curve number precedent 2nd Joint Federal Interagency Conference, Las Vegas, NV, 27 June-1 July 2010.

Janiszewski, F.: Pomiary zawartości wody w śniegu, Instrukcja dla stacji meteorologicznych, Wyd. Geologiczne Warszawa, 164 pp., 1988.

Miler, A.: Ocena wpływu zmian użytkowania terenu na odpływy wezbraniowe przy użyciu metody CN - SCS, Rocznik Ochrony Środowiska, T 14, 512-524, 2012.

Stewart, D., Canfield, E., and Hawkins, R.: Curve Number determination methods and uncertainty in hydrologic soil groups from semiarid watershed data, J. Hydrol. Eng., 17, 1180-1187, 2012.

Tedela, N. H., McCutcheon, S. C., Rasmussen, T. C., Hawkins, R. H., Swank, W. T., Campbell, J. L., Adams, M. B., Jackson, R., and Tollner, E. W.: Runoff Curve Numbers for 10 small forested watersheds in the mountains of the Eastern United States, J. Hydrol. Eng., 17, 1188-1198, 2012.

Van Mullem, J. A., Woodward, D. E., Hawkins, R. H., Hjelmfelt, A. T., and Quan, Q. D.: Runoff Curve Number method: Beyond the Handbook, Proceedings of Second Federal Interagency Hydrologic Modeling Conference, Las Vegas, Nevada, 2002. 